\title{
ENHANCEMENT OF ADAPTIVE CAPACITY OF SUGAR BEET CROPS BY MICROBIAL BIOPREPARATIONS UNDER BIOTIC AND ABIOTIC STRESSES
}

\section{L.I. PUSENKOVA' ${ }^{\text {, E.Yu. IL'YASOVA }}{ }^{1}$, I.V. MAKSIMOV ${ }^{2}$, O.V. LASTOCHKINA ${ }^{1}$}

${ }^{1}$ Bashkir Scientific Research Institute of Agriculture, Ufa Scientific Center of Russian Academy of Sciences, 19, ul. Rikharda Zorge, Ufa, 450059 Russia, e-mail L.Pusenkova@mail.ru;

2Institute of Biochemistry and Genetics, Ufa Scientific Center of Russian Academy of Sciences, 71, Prospekt Oktyabrya, Ufa, 450054 Russia, e-mail phyto@anrb.ru

Supported by Russian Foundation for Basic Research

Received February 18, 2014

\section{Abstract}

Diseases caused by pathogenic micromycetes and impact of herbicides lead to lower productivity and quality of sugar beet. Biopreparations based on Bacillus Cohn are promising environmentally friendly agents for plants protection under biotic and abiotic stresses. Meanwhile it is important to search of bioregulators for application on sugar beet and identify the mechanisms of their actions for effective use. This study summarizes the results of analysis of the effect of Bacillus Cohn based biopreparations Fitosporin-M, Albit, Vitaplan on structure of pathogenic mycromicetes complex in sugar beet (Beta vulgaris L., cv. KVS) rhizosphere, enzymatic activities in soil and leaves, sucrose content in roots and productivity under pathogenic and herbicides pressing. Evaluations were carried out using classical microbiological, physiological and biochemical methods. It was revealed that Fitosporin-M, Albit, Vitaplan decreased the abundance and frequency of rhizosphere pathogenic species and thus lead to activation of useful microflora. Partilularly, a total of 8 pathogenic micromycetes were found in control of which Alternaria tenuis, Aspergillus niger and Penicillium glabrum, the last two being strong toxigenic isolates, were dominant. After a single treatment with FitosporinM only Penicillium glabrum was found in the rhizosphere, in case of Albit there was only P. citrinum, and at Vitaplan application Alternaria tenuis, Aspergillus niger, Fusarium oxysporum, F. solani and Penicillium solitum were identified. In plants treated with Fitosporin-M and Albit, no Black Leg pathogens were observed. After doubled treatment the abundance decreased 1.5-3.0-fold, and the frequency decreased 2.0-4.0-fold compared to control. Catalase activity reflecting intensity of soil microbiological processes exceeded control from 1.4 to 3.7 times after the first treatment with Fitosporin-M and Albi, respectively, and from 1.4 to 1.2 times after the second one. The data on increasing oxidoreductases and hydrolases activities in rhizosphere confirm this conclusion. Also, biopreparations decreased activities of hydrolases in leaves and the activity of their inhibitors indicating induction of protective reactions against pathogens. The maximum values were recorded when Fitosporin-M and Albit were used. The protective actions of biopreparations were also indicated by activation of peroxidase in leaves up to $0.175-0.250 \mathrm{OD}_{490}$ per $1 \mathrm{~g}$. Furthermore Fitosporin-M supported a relatively high level after reintroduction indicating a prolonged action on the antioxidant system during vegetation. The positive effect of biopreparations under pathogenic and herbicides pressing was reflected in increasing productivity and sucrose content in sugar beet roots, and the maximum effect was achieved after 2-fold treatment of sowings with Fitosporin-M.

Keywords: Bacillus Cohn based biopreparations, oxidoreductases, hydrolases, peroxidase, sucrose, pathogenic microbiota, herbicides pressing, resistance, productivity, Beta vulgaris L.

The sugar beet (Beta vulgaris L.) is one of the most important industrial crops for sugar production [1]. At the same time, its potential productivity remains unrealized because the plants are adversely affected by various stress factors of both biotic (diseases and pests) and abiotic (exposure to high and low temperatures, moisture deficit, pesticide pressing, etc.) nature, which leads to decrease in root crop weight gain intensity and sugar content [2-4]. Significant crop losses (especially in recent years) are caused by the diseases of the root system (root rots) and leaves (necrotic spots), the pathogens of which may later cause clamp rots [5,6], as well as by the widespread use of herbicides in the 
plant vegetation period [2]. In this connection, it continues to be very important to select various environmentally safe bioregulators having a positive influence on the phytosanitary condition of sugar beet crops and increasing the degree of plant cell homeostatic state and tolerance under stress conditions [2, 3].

As compared to chemical pesticides, microbial biopreparations used for plant enhancement and protection against adverse environmental factors have a number of advantages associated with their environmental safety and systemic immunomodulatory action [7-11]. Along with low toxicity, biopreparations based on living bacterial cultures are characterized by a polyfunctional effect and a broad spectrum of action with regard to various plants and pathogens, and are not expensive $[12,13]$. It is reported that associative microorganisms perform a series of functions which are useful for the host plant, particularly, they promote plant growth and development (synthesis of hormones, vitamins), facilitate biocontrol of pathogens (synthesis of antibiotics, induction of systematic resistance), and increase the intensity of root assimilation of nutrients including nitrogen, phosphorus and potassium [14-19]. Interaction with the microbial community of the rhizosphere has a positive influence on the plant, improving its resistance to biotic $[15,16,20,21]$ and abiotic environmental factors [22-26]. In particular, it is known that biopreparations based on endophytic bacteria Bacillus Cohn improve the adaptive potential of wheat plants under abiotic stresses [22, 25, 27] and have a favorable influence on plant immunity [12, 20, 28, 29]. Plant treatment with biological preparations based on symbiotic and endophytic microorganism strains with a set of properties improving the microbial diversity of the rhizosphere is a promising way to increase the productivity of agricultural crops $[9,13,30,31]$. However, in spite of numerous studies, the sequence of plant reactions of the stress resistance induced by bacillar biopreparations is not completely understood and requires further investigation. In addition, there are limited data on their influence on sugar beet plants in conditions of various stress factors, in particular, pathogen and herbicide pressing, which makes it difficult to more effectively use the already existing microbial biopreparations for the purpose of targeted control of plant resistance.

The purpose of this work was to assess the influence of biopreparations based on Bacillus Cohn and their metabolites on the structure of the complex of pathogenic micromycetes in the plant rhizosphere, on enzymatic activity in soil and leaves, as well as on the dynamics of saccharose accumulation in the root crops of the sugar beet and their productivity under the influence of pathogenic soil microflora and herbicides.

Technique. Field trials were carried out in 2010-2011 on crops of the sugar beet (Beta vulgaris L.) of KWS hybrid (Singenta LLC, Russia) under the conditions of the Pre-Ural steppe zone of the Republic of Bashkortostan (Chishmy Agroinvest LLC). The soil characteristics of the trial field were as follows: leached chernozem, $\mathrm{pH} 5.4, \mathrm{Hg}$ at $5.64 \mathrm{meq} / 100 \mathrm{~g}$ of soil, humus content of $8.72 \%$, phosphorus and potassium level at 24.8 and $30 \mathrm{mg} / 100 \mathrm{~g}$ of soil, respectively. The sugar beet cultivation technology was the same in all trial variants and corresponded to the one commonly used in the region. Crop protection against weeds was provided by triple treatment with a complex of herbicides Lontrel-300 (0.3 1/ha; Avgust, Russia), Betanal 22 (1.5 1/ha; Bayer CropScience, Russia) and Fusilade Forte (1 1/ha; Singenta LLC, Russia). The trials were established in compliance with procedural guidelines [32]. The following preparations were used: Phytosporin-M (rate of application at $11 /$ ha, endophytic strain of Bacillus subtilis 26D as active agent; NVP BashInkom, Russia), Vitaplan ( $40 \mathrm{~g} / \mathrm{ha}$, mixture of Bacillus subtilis strains; CJSC Agrobiotekhnologiya, Russia), Albit ( $40 \mathrm{ml} / \mathrm{ha}$; poly- $\beta$-hydroxybutyric acid produced by soil bacteria $\mathrm{Ba}$ - 
cillus megaterium and Pseudomonas aureofaciens; NPF Albit LLC, Russia). The preparations were applied in tank mixtures with herbicides two times $\left(1^{\text {st }}\right.$ and $2^{\text {nd }}$ treatments at the stages of 2-3 and 4-6 pairs of true leaves, respectively). In each trial variant the area of production plots was 0.5 ha, 3 replicates; and the area of record plots was $25 \mathrm{~m}^{2}, 4$ replicates. Assessments were made at the stages of 2-3 and 4-6 pairs of true leaves.

Isolation and quantitation of microorganisms on trial plots were carried out in accordance with a method for soil suspension inoculation on solid agarized media [33]. Species of micromycetes were identified using guides [34, 35]. Specific names of fungi were clarified using the updated lists published in the Index Fungorum database (http://www.indexfungorum.org).

On the days 4 and 10 after the start of the experiment, the part of leaves from the test plants was fixed in liquid nitrogen for further biochemical studies. The samples were triturated in porcelain mortars in $0.05 \mathrm{M}$ Na-phosphate buffer ( $\mathrm{PB}, \mathrm{pH}$ 6.2) (1:5 weight/volume) and, after extraction of proteins for $60 \mathrm{~min}$ at $4{ }^{\circ} \mathrm{C}$, centrifuged for $10 \mathrm{~min}$ at $15,000 \mathrm{~g}$.

The activity of peroxydase in aliquots was determined using a micromethod. An aliquot of enzyme sample $(0.075 \mathrm{ml})$ prediluted in $0.01 \mathrm{M} \mathrm{Na}-$ phosphate buffer (at sample to buffer rate of $1: 50$ ) and $0.025 \mathrm{ml}$ of $0.5 \mathrm{mg} / \mathrm{ml}$ o-phenylenediamine solution was added in each well of flat-bottom immunology plates. After addition of $0.025 \mathrm{ml}$ of $0.016 \% \mathrm{H}_{2} \mathrm{O}_{2}$, staining was stopped after 2 min by adding $0.05 \mathrm{ml}$ of $4 \mathrm{~N} \mathrm{H}_{2} \mathrm{SO}_{4}$. The plate was scanned at $\lambda=490 \mathrm{~nm}$ on an IFA-Reader spectrophotometer (Poland) [14]. The activity of hydrolases was determined in the plant extracts after homogenization in buffered solution $(0.05 \mathrm{M}$ Tris- $\mathrm{HCl}, \mathrm{pH} 8.0$, and $0.05 \mathrm{M} \mathrm{NaCl}$ ) for $12 \mathrm{hrs}$ in the ratio 1:30 (sample weight, g/extractant volume, $\mathrm{ml}$ ) at $4{ }^{\circ} \mathrm{C}$. The activity of proteases was taken into account using gelatin plates as recommended [36]. A layer of agarose gel was formed on the gelatin plate surface; $5 \mathrm{~mm}$ diameter wells were cut out in it; then, their edges were melted, and $50 \mu$ of protein extract was added into each well. Upon completion of incubation, agarose gel was removed, and the plate was washed with running water in order to remove the hydrolyzed areas which then were easily seen against a dark background in the form of round light spots. The circle diameter was used as a basis for estimating the size of the hydrolyzed area, and the activity was recounted from the curve of the trypsin standard solutions pretitrated on the same plate. The lower limit of activity quantification for the commercial trypsin preparation was $0.5-1.0 \mu \mathrm{g}$. The activity of catalase, dehydrogenase, polyphenoloxidase, peroxydase, protease and urease in soil from the zone adjacent to the rhizosphere was measured in extracts by the method proposed by the F.Kh. Khaziyev (37); saccharose content in sugar beet root crops was determined using a polarimeter (P161-M, Russia) by the cold water digestion method [38].

Statistical processing of the obtained results was carried out using the analysis-of-variance method [39]. The calculations of the experimental data was performed using the Microsoft Excel software. The histograms show average values and their standard deviations.

Results. High yields of agricultural crops largely depend on both the agrochemical condition of soil and the presence of appropriate microflora in it [30]. Thus, the microbial community in the rhizosphere of the plant improves its resistance to biotic [15] and abiotic stress factors [8, 24], but the large number of pathogenic and opportunistic microorganism species produces a negative effect due to development of various diseases leading to reduction in productivity and quality of root crops, as well as their storage life.

The significant decrease in sugar beet productivity due to the diseases of 
the root system (rots) and leaves (necrotic spots) has been noted in recent years. In future, the corresponding pathogens may cause clamp rots $[4,6]$. The works to reduce losses due to diseases, in particular, root rots, with the use of microorganism-based biopreparations are being performed very actively now $[2,3,6$, 40], and a special emphasis is put on the study of the microbiological processes occurring in soil and plant rhizosphere. In this regard, the interest to the rhizosphere as a zone of maximum accumulation and functional activity of soil microorganisms becomes more profound [30, 41, 42]. Our study of the influence of microbial biopreparations Phytosporin-M, Vitaplan and Albit on a complex of micromycetes in the sugar beet rhizosphere has demonstrated that, at the stage of 2-3 pairs of true leaves, it was possible to extract up to 38 microfungus species from the mentioned soil zone, and 28 strains of them were identified as representatives of three genera, Aspergillus, Penicillium and Fusarium (5, 20 and 3 strains, respectively). The genera Alternaria, Rhizopus and Trichoderma were significantly less represented (Table 1).

1. The change of pathogenic mycobiota composition in the rhizosphere of sugar beet (Beta vulgaris L., KWS hybrid) root crops after treatment with biopreparations against the use of herbicides (Chishmy Agroinvest LLC, Republic of Bashkortostan, 2010-2011)

\begin{tabular}{|c|c|c|c|c|}
\hline \multirow{2}{*}{ Species } & \multicolumn{4}{|c|}{ Abundance of species, unit/frequency, $\%$} \\
\hline & control & Phytosporin-M & Albit & Vitaplan \\
\hline \multicolumn{5}{|c|}{ Single treatment at $2-3$ true 1 eaves } \\
\hline Alternaria tenuis $\mathrm{Nees}^{1}$ & $12.1 / 40$ & - & - & $5.3 / 20$ \\
\hline Aspergillus niger Tiegh. ${ }^{1}$ & $9.1 / 40$ & - & - & $5.3 / 20$ \\
\hline Aspergillus parvulus $\mathrm{G} . \mathrm{Sm} .^{2}$ & $3.0 / 20$ & - & - & - \\
\hline \multicolumn{5}{|l|}{ Fusarium oxysporum var. Orthoceras Appel } \\
\hline \& Wollenw. 2 & $6.1 / 40$ & - & - & $5.3 / 20$ \\
\hline Fusarium solani Appel2 & - & - & - & $2.6 / 20$ \\
\hline Fusarium solani var. agrillaceum ${ }^{2}$ & $6.1 / 40$ & - & - & - \\
\hline Penicillium aurantiogriseum Dierckx ${ }^{1}$ & $15.2 / 80$ & - & - & - \\
\hline Penicillium glabrum Wehmer ${ }^{2}$ & $9.1 / 40$ & $3.1 / 20$ & - & - \\
\hline Penicillium citrinum Thom ${ }^{2}$ & - & - & $8.1 / 40$ & - \\
\hline Penicillium solitum var. crustosum Thom 1 & - & - & - & $2.6 / 20$ \\
\hline Rhizopus microsporus Tiegh. ${ }^{2}$ & $6.1 / 20$ & - & - & - \\
\hline \multicolumn{5}{|c|}{ Double treatment at 6-8 true leaves } \\
\hline Alternaria tenuis (Fr.) Keissl. ${ }^{1}$ & $7.0 / 40$ & $5.9 / 20$ & - & - \\
\hline Aspergillus flavus Link ${ }^{2}$ & $3.5 / 20$ & - & - & - \\
\hline Aspergillus niger Tiegh ${ }^{1}$ & $10.5 / 80$ & $3.0 / 20$ & $2.6 / 20$ & $2.8 / 20$ \\
\hline Fusarium oxysporum Schltdl. ${ }^{2}$ & $3.5 / 40$ & - & - & - \\
\hline Fusarium solani var. agrillaceum C. Booth ${ }^{2}$ & $7.0 / 60$ & $5.9 / 20$ & - & - \\
\hline Penicillium aurantiogriseum Direckx. ${ }^{1}$ & $14.0 / 80$ & - & $5.1 / 40$ & $5.6 / 20$ \\
\hline Penicillium glabrum Wehmer ${ }^{2}$ & $19.3 / 100$ & - & - & - \\
\hline Penicillium solitum var. crustosum Thom 1 & - & $3.0 / 20$ & - & - \\
\hline
\end{tabular}

As may be inferred from the presented data (see Table 1), 8 species of pathogenic micromycetes were found in soil from control plots which were not treated with the biopreparations; according the classification proposed by A.V. Kornienko [5], they include 3 sugar beet Pythium disease pathogens (Penicillium aurantiogriseum, Alternaria tenuis, Aspergillus niger) and 5 root system disease pathogens (clamp rot) (Penicillium glabrum, Fusarium solani var. agrillaceum, F. oxysporum, Aspergillus parvulus, Rhizopus microsporus). Alternaria tenuis, Aspergillus niger and Penicillium glabrum were dominant species. It should be noted that the last two of them are strong toxin producers: they release substances which can weaken and subsequently kill plants and cause the reduction of root crop quality [43].

Sugar beet plant treatments with biopreparations Phytosporin-M, Albit and Vitaplan promoted the change of microfungus species composition in the rhizosphere of the sugar beet. Thus, after single treatment of plants, pathogenic 
fungi in the root crop rhizosphere were represented by only one species, Penicillium glabrum, in case of Phytosporin-M, $P$. citrinum in case of Albit, and 5 species (Alternaria tenuis, Aspergillus niger, Fusarium oxysporum, F. solani and Penicillium solitum) in case of Vitaplan (see Table 1). It is also important that there were no Pythium disease pathogens on the plots treated with Phytosporin-M and Albit.

The mycobiota species composition in the rhizosphere of sugar beet control plants at the stage of 6-8 leaves remained almost unchanged, except for the appearance of the species Aspergillus flavus Link causing clamp rot (see Table 1). At the same time, only two Pythium disease pathogens, Aspergillus niger and Penicillium aurantiogriseum, were revealed after double treatment of crops with biopreparations Albit and Vitaplan, and their occurrence rate was 4 times less as compared to the control. Three Pythium disease pathogens and one clamp rot pathogen were found in case of treatment with Phytosporin-M. In this trial variant, the abundance of species and their occurrence rate were 1.5-3.0 times less and 2.0-4.0 times less, respectively, than in the control. Thus, plant treatments with the biopreparations reduced the abundance of species and occurrence rate of pathogenic micromycetes in the rhizosphere of the sugar beet.

The activation of beneficial soil microbiota under the influence of biopreparations, undoubtedly, leads to changes in the biochemical condition of the soil, in particular, its enzymatic activity, which may have a significant impact on plant productivity [19]. Earlier, we demonstrated that sugar beet plant treatments with biopreparations Albit and Phytosporin-M had a positive influence on the activity of oxidoreductases and hydrolases in the rhizosphere of the sugar beet [42]. In the experiment, the activity of catalase reflecting the intensity of microbiological processes in soil was 1.4 and 3.7 times higher than that of the control after the first treatment with Phytosporin-M and Albit, respectively; after the second treatment, it was 1.4 and 1.2 times higher, respectively.

Plant treatments with Phytosporin-M and Vitaplan stimulated the development of agronomically beneficial microbiota under sugar beet crops, leading to increase in the total quantity of microorganisms consuming organic nitrogen forms, as well as increase in the number of microorganisms breaking up complex polymeric compounds and the number of nitrogen-fixing bacteria [42]. The obtained results are consistent with the published data on mechanisms for induction of productive qualities of plants under the influence of microorganisms [30, 44].

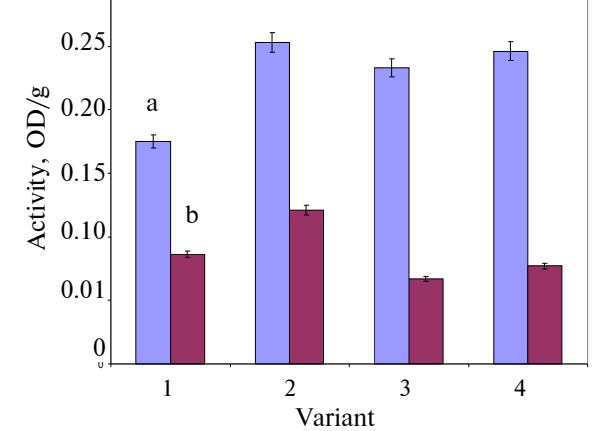

The dynamics of peroxidase activity in sugar beet (Beta vulgaris L., KWS hybrid) leaves under plant treatment with biopreparations against the use of herbicides: $\mathrm{a}-1^{\text {st }}$ treatment, $\mathrm{b}-2^{\text {nd }}$ treatment (Chishmy Agroinvest LLC, Republic of Bashkortostan, 2010-2011).
It is known that, in response to harmful impacts, an oxidative stress is developed in plants, and peroxidase plays an important role in its neutralization $[14,16]$. In all variants, statistically significant activation of peroxidase in leaves was observed after plant treatment with biopreparations (Fig.). Earlier we noted such increase in peroxidase activity for wheat and potato plants under the influence of biopreparations [12, 14]. After reapplication of biopreparations, decrease in peroxidase activity was observed in all samples, except for the variant with Phytosporin-M, where this parameter remained higher than in the control, which

is probably indicative of the long-lasting action of the preparation on the anti- 
oxidant system of the plant.

The formation of protective mechanisms against pathogens in plants largely depends on hydrolytic enzymes (proteases, amylases, pectinase) and their inhibitors. Earlier, in model experiments on potato tubers, we demonstrated that prolonged activation of protease inhibitor synthesis improved the protection of the tubers treated with Phytosporin-M against penetration and development of pathogenic microorganisms [36].

Sugar beet plant treatment with biopreparations reduced the activity of hydrolases in leaves (Table 2) and, conversely, increased the activity of their inhibitors, which is indicative of induction of protective reactions against pathogens in plants; maximum values were registered in case of treatments with biopreparations Phytosporin-M and Albit.

2. The dynamics of hydrolytic enzyme activity (IU/g fresh weight) in sugar beet (Beta vulgaris L., KWS hybrid) leaves after treatment with biopreparations against the use of herbicides $(X \pm X$, Chishmy Agroinvest LLC, Republic of Bashkortostan, 2010-2011)

\begin{tabular}{|c|c|c|c|c|c|c|}
\hline \multirow{2}{*}{ Variant } & \multicolumn{3}{|c|}{$4^{\text {th }}$ day after treatment } & \multicolumn{3}{|c|}{$10^{\text {th }}$ day after treatment } \\
\hline & protease & amylase & pectinase & protease & amylase & pectinase \\
\hline \multicolumn{7}{|c|}{ Single treatment with } \\
\hline Control & $6.43 \pm 0.23$ & $7.12 \pm 0.14$ & $4.46 \pm 0.12$ & $6.67 \pm 0.10$ & $8.22 \pm 0.11$ & $5.76 \pm 0.24$ \\
\hline Phytosporin-M & $3.12 \pm 0.13$ & $2.57 \pm 0.23$ & $2.76 \pm 0.12$ & $2.77 \pm 0.12$ & $3.68 \pm 0.13$ & $4.11 \pm 0.15$ \\
\hline Albit & $2.89 \pm 0.13$ & $3.03 \pm 0.21$ & $3.33 \pm 0.23$ & $3.67 \pm 0.24$ & $3.88 \pm 0.22$ & $3.58 \pm 0.12$ \\
\hline Vitaplan & $3.67 \pm 0.14$ & $3.43 \pm 0.12$ & $3.86 \pm 0.21$ & $3.21 \pm 0.11$ & $3.76 \pm 0.10$ & $3.34 \pm 0.21$ \\
\hline \multicolumn{7}{|c|}{ Double treatment with } \\
\hline Control & $5.78 \pm 0.22$ & $6.65 \pm 0.23$ & $4.03 \pm 0.31$ & $6.77 \pm 0.12$ & $8.72 \pm 0.11$ & $5.76 \pm 0.25$ \\
\hline Phytosporin-M & $3.23 \pm 0.10$ & $3.21 \pm 0.12$ & $3.03 \pm 0.32$ & $2.77 \pm 0.19$ & $3.68 \pm 0.22$ & $3.21 \pm 0.17$ \\
\hline Albit & $3.43 \pm 0.09$ & $2.67 \pm 0.14$ & $2.78 \pm 0.22$ & $3.57 \pm 0.12$ & $3.58 \pm 0.24$ & $3.58 \pm 0.21$ \\
\hline Vitaplan & $2.48 \pm 0.13$ & $3.26 \pm 0.12$ & $3.24 \pm 0.12$ & $3.21 \pm 0.12$ & $3.76 \pm 0.13$ & $3.34 \pm 0.12$ \\
\hline
\end{tabular}

The resultant indicators of physiological-biochemical and microbiological processes in plants throughout the vegetation period are the indices of productivity and quality of sugar beet root crops. Thus, the application of the studied biopreparations led to increase in root crop productivity by 1.6-5.0 t/ha as compared to the control and helped in more intensive accumulation of sweeteners in the crops. Whereas the saccharose content in the control achieved $16.2 \%$ by the time of harvesting, it ranged within 17.0-18.8 \% between the variants of the trial, and the highest values were obtained in case of double treatment of crops with Phytosporin-M.

So, the obtained data support the conclusion that the biopreparations based on Bacillus Cohn and their metabolites improve the yielding capacity and quality of sugar beet root crops by the correction of microflora composition in the rhizosphere, in particular, due to reduction in the number and species diversity of pathogenic micromycetes, which, in turn, reduces the probability of plants being infected by root system and leaf disease pathogens. In addition, an important contribution to the formation of productivity and the growth of plant resistance to adverse environmental factors (in particular, to pathogen and herbicide pressing) is probably made by the increase of enzymatic activity both in the rhizosphere and leaves of the sugar beet due to the influence of biopreparations. In general, it can be concluded based on the results of the study that the application of such biopreparations as Phytosporin-M, Albit and Vitaplan leads to reduction in plant disease incidence rate and increase in productivity and quality of sugar beet root crops under the influence of pathogenic micromycetes and herbicide pressing. In this regard, the most profound effect was noted for Phytosporin-M, which allows us to recommend using it in technologies for intensive cultivation of the sugar beet. 


\section{REFERENCES}

1. Pathak A.D., Kapur R., Solomon S., Kumar R., Srivastava S., S ingh P.R. Sugar beet: a historical percpective in Indian context. Sugar tech., 2014, 16(2): 125-132.

2. A lekhin V.T., Ryabchinskaya T.A., Kharchenko G.L., Bobreshkova I.Yu., S a r a n ts e va N.A. Sakharnaya svekla, 2010, 2: 16-22.

3. B argabus R.L., Zidack N.R., She rwood J.W., J a cobsen B.J. Screening for the identification of potential biological control agents that induce systemic acquired resistance in sugar beet. Biol. Control, 2004, 30: 342-350.

4. Collins D.P., J a cobse n B.J. Optimizing a Bacillus subtilis isolate for biological control of sugar beet cercospora leaf spot. Biol. Control, 2003, 26(2): 153-161.

5. Ko rnie n k o A.V. Agro XXI, 2006, 1-3: 25-29.

6. S e liv a n o v a G.A., S t o g n i e n k o O.I. Zashchita rastenii, 2010, 6: 16-17.

7. Frave 1 D.R. Commercialization and implementation of biocontrol. Ann. Rev. Phytopathol., 2005, 43: 337-359.

8. Ts avkelova E.A., Kli mova S.Yu., Cherdyntseva T.A., Netrusov A.I. Prikladnaya biokhimiya i mikrobiologiya, 2006, 42(2): 133-143.

9. Mon astyrski i O.A., Pershak ova T.V. Agro XXI, 2009, 7-9: 3-5.

10. Perez-Garcia A., Ro me ro D., de Vicente A. Plant protection and growth stimulation by microorganisms: biotechnological applications of Bacilli in agriculture. Curr. Opin. Biotechnol., 2011, 22: 187-193.

11. B a y s a 1 O., T o r M. Smart biologics for crop protection in agricultural systems. Turk. J. Agric. For., 2014, 38: 723-731.

12. M a ks i mov I.V., P u se nk ova L.I., A bi zg i l'd i n a R.R. Agrokhimiya, 2011, 6: 43-48.

13. K a y $\mathrm{mak}$ H.C. Potential of PGPR in agricultural innovations. Plant growth and health promoting bacteria. Microbiology Monograph, 2011, 18: 45-79.

14. Maksimov I.V., Abizgil'dina R.R., Yusupova Z.R., Khairullin R.M. Agrokhimiya, 2010, 1: 55-60.

15. Whipps J.M. Microbial interactions and biocontrol in the rhizosphere. J. Exp. Bot., 2001, 52: 487-511.

16. Shaki rova F.M., S a k habutd i nova A.R. Uspekhi sovremennoi biologii, 2003, 123(6): 563-572.

17. Dak h mush A.S., K o z h e m y a k ov A.P. Agrokhimiya, 2007, 1: 57-61.

18. Kats y E.I. Molekulyarnaya genetika assotsiativnogo vzaimodeistviya bakterii i rastenii [Molecular genetics of bacterial-plant association]. Moscow, 2007.

19. Mele nt'ev A.I. Aerobnye sporoobrazuyushchie bakterii Bacillus Cohn v agroekosistemakh [Aerobic spore forming bacteria Bacillus Cohn in agroecosystems]. Moscow, 2007.

20. Kuz' mina L.Yu., Pak ho mova T.B., Mak s i mov I.V. Agrokhimiya, 2012, 10: 39-45.

21. Compant S., Duffy B., Clement C., Barka E.A. Use of plant growth promoting bacteria for biocontrol of plant diseases: principles, mechanisms of actions, and future prospects. Appl. Environ. Microbiol., 2005, 94: 4951-4959.

22. B ochow H., El-S ayed S., Junge H., S tavropoulou A., Schmiedekn$\mathrm{e} \mathrm{cht} \mathrm{G.} \mathrm{Use} \mathrm{of} \mathrm{Bacillus} \mathrm{subtilis} \mathrm{as} \mathrm{biocontrol} \mathrm{agent.} \mathrm{IV.} \mathrm{Salt-stress} \mathrm{tolerance} \mathrm{induction} \mathrm{by} \mathrm{Ba-}$ cillus subtilis FZB24 seed treatment in tropical vegetable field crops, and its mode of action. $J$. Plant Dis. Protect., 2001, 108(1): 21-30.

23. Arkhipova T.N., Melent'ev A.I., Veselov S.Yu., Kudoyarova G.R. Agrokhimiya, 2004, 3: 69-73.

24. Yang J., Klopper J.W., Ryu C.-M. Rhizosphere bacteria help plants tolerate abiotic stress. Trends Plant Sci., 2009, 14(1): 1-8.

25. Khairulli n R.M., Nedorezkov V.D., Mubinov I.G., Z Zakharova R.Sh. Vestnik Orenburgskogo gosudarstvennogo universiteta, 2007, 2: 129-134.

26. Sokolova M.G., Akimova G.P., S otnikova I.V., Nechaeva L.V. Sibirskii vestnik sel'skokhozyaistvennoi nauki, 2009, 1: 25-29.

27. Mubi nov I.G. Reaktsii pshenitsy na deistvie kletok endofitnogo shtamma $26 \mathrm{D}$ Bacillus subtilis - osnovy biofungitsida Fitosporin. Kandidatskaya dissertatsiya [Response of wheat plant to cells of endophytic Bacillus subtilis 26D strain, the base component of Fitosporin fungicide. PhD Thesis]. Ufa, 2007.

28. J a c obse $\mathrm{n}$ B.J., Z i d a ck N.K., Lars o n B.J. The role of Bacillus-based biological control agents in integrated pest management systems: plant diseases. Phytopathology, 2004, 94: 1272-1275.

29. Castillo H.F.D., Reyes C.F., Moralles G.G., Herrera R.R., Aguilar C. Biological control of root pathogens by plant-growth promoting Bacillus spp. Agricultural and Biological Sciences. Ch. 4. Weed and pest control - conventional and new challenges. Open access, 2013 (doi: 10.5772/54229).

30. $\mathrm{Kr}$ a f $\mathrm{A}$.V. Vliyanie effektivnykh mikroorganizmov na mikrobnoe soobshchestvo chernozema vyshchelochennogo i produktivnost' sakharnoi svekly. Kandidatskaya dissertatsiya [The influence 
of effective microorganisms on microbial communoty of leached cherozem and sugar beet yield. PhD Thesis]. Ramon', 2004.

31. Ku mar A., Prak as A., Johri B.N. Bacillus as PGPR in crop ecosystem. In: Bacteria in agrobiology: crop ecosystems. D.K. Maheshwari (ed.). Berlin, Springer, 2011: 37-59.

32. Metodicheskie ukazaniya po registratsionnym ispytaniyam fungitsidov $v$ sel'skom khozyaistve [Tests for registration of fungicides in agriculture: guidelines]. St. Petersburg, 2009.

33. Miftak hova A.M., K i re e va N.A., B a k a e va M.D. Ekologiya pochvennykh mikromitsetov [Ecology of soil micromycetes]. Ufa, 2005.

34. B i 1 a i V.I. Fuzarii [Fusarium]. Kiev, 1977.

35. B i l a i V.I., Koval' E.Z. Aspergilly [Aspergillus]. Kiev, 1988.

36. I b r a g i mov R.I. Belkovye ingibitory proteoliticheskikh fermentov $\mathrm{i}$ ikh rol' $\mathrm{v}$ formirovanii gomeostaticheskikh reaktsii u rastenii. Avtoreferat doktorskoi dissertatsii [Protein inhibitors of proteolytic enzymes and their involvement into homeostatic reactions in plants. DSci Thesis]. Ufa, 1999.

37. K haziev F.Kh. Metody pochvennoi enzimologii [Methods of soil enzymology]. Moscow, 2005.

38. Metodika opredeleniya khimicheskogo sostava i pokazatelei kachestva sakharnoi svekly [Sugar beet: chemical analysis and quality control techniques]. Kursk, 2001.

39. D o s p e k hov B.A. Metodika polevogo opyta [Methods of field trials]. Moscow, 1979.

40. Zlot nikov A.K. Razrabotka i kompleksnaya kharakteristika polifunktsional'nogo preparata Al'bit dlya zashchity rastenii ot boleznei i stressov. Avtoreferat doktorskoi dissertatsii [Development andcharacteristics of Albit, a polyfunctional preparation for plant protection against diseases and stresses. DSci Thesis]. Voronezh, 2012.

41. S hirokikh A.A., M e rza e v O.V., Sh irokikh I.G. Sel'skokhozyaistvennaya Biologiya [Agricultural Biology], 2007, 1: 43-55.

42. Puse n k ova L.I., I l' y a s ova E.Yu., K i re e va N.A. Agrokhimiya, 2012, 10: 20-26.

43. B e r e s t e ts k i i O.A. V sbornike: Fitotoksicheskie svoistva pochvennykh mikroorganizmov [In: Phytotoxic properties of soil microorganusms and their ecological role]. Leningrad, 1978: 7-30.

44. $\mathrm{Z}$ a v a 1 i n A.A. Biopreparaty, udobreniya i urozhai [Biopreparations, fertilizers and crop yield]. Moscow, 2005. 